\title{
Hubungan Pengetahuan Kode Etik Kedokteran Indonesia dengan Kejadian Kekerasan di Wahana Pendidikan Klinis pada Dokter Muda di Surakarta
}

\author{
Yudhistira Andarusukma1, Adji Suwandono², Wahyu Dwi Atmoko \\ 1. Program Studi Kedokteran, Universitas Sebelas Maret Surakarta \\ 2. Instalasi Kedokteran Forensik \& Medikolegal, RSUD Dr. Moewardi Surakarta \\ Korespondensi : yudhistira.andra8@gmail.com
}

\begin{abstract}
ABSTRAK
Pendahuluan: Kekerasan di tempat kerja terhadap tenaga kesehatan saat ini berada dalam taraf yang mengkhawatirkan seiring dengan naiknya angka kejadian tersebut. Hal ini juga dialami oleh dokter muda dalam menjalani masa studinya pada program profesi dokter di wahana pendidikan klinis. Salah satu faktor yang menyebabkan hal tersebut berkaitan dengan penerapan etika profesi saat bekerja. Etika profesi dokter diatur dalam Kode Etik Kedokteran Indonesia yang ditujukan untuk mempertahankan hubungan kepercayaan dokter-pasien. Pengetahuan yang memadai mengenai kode etik menimbulkan sikap yang sesuai dengan ketentuan yang harusnya dilakukan, sehingga diharapkan mampu mengurangi risiko terjadinya gesekan yang berujung pada terjadinya kekerasan. Penelitian ini ditujukan untuk mengetahui apakah terdapat hubungan pengetahuan Kode Etik Kedokteran Indonesia dengan kejadian kekerasan di wahana pendidikan klinis.

Metode: Penelitian ini bersifat observasional analitik dengan pendekatan cross sectional yang dilaksanakan pada bulan Januari hingga Februari 2020 pada dokter muda RSUD dr. Moewardi Surakarta. Pengambilan subjek dilakukan dengan teknik purposive sampling. Data yang didapat dianalisis menggunakan uji korelasi Pearson dan uji regresi linier sederhana.

Hasil: Hasil analisis data pada 54 subjek penelitian menunjukkan hubungan negatif antara pengetahuan tentang kode etik kedokteran dengan kejadian kekerasan di wahana pendidikan klinis $(\mathrm{r}=-0.313, \mathrm{p}=0,021)$. Pada analisis regresi linier sederhana didapatkan pengaruh antara kedua variabel $\left(\mathrm{r}^{2}=0.098\right.$, koefisien regresi $\left.=-0.364, \mathrm{p}<0,05\right)$.

Kesimpulan: Terdapat hubungan dan pengaruh yang bermakna secara statistik antara pengetahuan kode etik kedokteran dengan kejadian kekerasan di wahana pendidikan klinis dengan dengan kekuatan lemah dan arah korelasi negatif.
\end{abstract}

Kata Kunci: kekerasan di tempat kerja, wahana pendidikan klinis, dokter muda, program profesi dokter, pengetahuan kode etik kedokteran.

\begin{abstract}
Introduction: Workplace violence against health workers currently are rising at a worrying rate. This condition are also affecting medical students during their stage of clinical clerkship in teaching hospital. One of its contributing factors is related to the implementation of medical ethics during working. Here, medical ethic is regulated in Indonesian Medical Ethics Code, aimed to maintain the trust between doctor and patient. A better understanding of ethical code can result in better behavior that can potentially decrease the tension between doctor and patient. This research aims to find the correlation between the Indonesian Medical Ethics Code's knowledge and the occurrence of workplace violence among medical students during clinical clerkship.

Methods: This is an analytic observational research with cross-sectional approach conducted between January to February 2020. The subjects are medical students in clinical clerkship stage in Dr.Moewardi General Hospital Surakarta. The sample was
\end{abstract}


taken using purposive sampling method and the data was analyzed using Pearson correlation test and simple linear regression test.

Results: The analyzed data from 54 subjects resulted in a negative correlation between the Indonesian Medical Ethics Code's knowledge and the occurrence of workplace violence among clinical clerkship students $(r=-0.313, p=0.021)$ and both factors are influencing each othe $\left(r^{2}=0.098\right.$, regression slope $\left.=-0.364, p<0,05\right)$.

Conclusion: There is a statistically significant correlation and influence between Indonesian Medical Ethics Code's knowledge and the occurrence of workplace violence among medical student during clinical clerkship, resulted in a weak negative correlation.

Keywords: workplace violence, medical student, clinical clerkship, teaching hospital, Indonesian Medical Ethics Code

\section{PENDAHULUAN}

Pasal 31 ayat (1) a Undang-Undang Nomor 20 Tahun 2013 tentang Pendidikan Kedokteran menyebutkan bahwa setiap mahasiswa berhak memperoleh perlindungan hukum di Rumah Sakit Pendidikan dan Wahana Pendidikan ${ }^{1}$. Sayangnya, kekerasan dalam tempat kerja, yang melibatkan fisik, verbal, kebudayaan, suku-ras, dan seksual saat ini berada dalam taraf yang mengkhawatirkan seiring dengan terus naiknya angka kejadian tersebut $^{2}$. World Health Organization (WHO), International Labour Organization (ILO), International Council of Nurses (ICN), dan Public Services International (PSI), mengartikan kekerasan di tempat kerja sebagai suatu peristiwa ketika seorang pekerja (dalam konteks ini berarti dokter muda), dilecehkan, diancam atau diserang dengan motif yang berhubungan dengan pekerjaannya, kejadian ini meliputi kekerasan yang terjadi saat perjalanan menuju dan dari tempat kerja, yang melibatkan ancaman eksplisit maupun implisit terhadap keamanan, kesejahteraan atau kesehatannya ${ }^{3}$. Tempat kerja (workplace) yang dimaksud adalah fasilitas pelayanan kesehatan apapun, terlepas dari ukuran, lokasi (di perkotaan atau perdesaan) dan tipe pelayanan yang disediakan, meliputi rumah sakit rujukan utama di kota-kota besar, rumah sakit daerah, pusat kesehatan masyarakat, klinik, pusat rehabilitasi, praktik pribadi, ataupun tempat pelayanan kesehatan lainnya ${ }^{3}$.
Dalam hal ini, dokter muda memiliki tempat kerja berupa wahana pendidikan klinis. Wahana pendidikan klinis yang dimaksud penulis terdiri dari rumah sakit pendidikan dan wahana pendidikan kedokteran. Rumah Sakit Pendidikan adalah rumah sakit yang mempunyai fungsi sebagai tempat pendidikan, penelitian, dan pelayanan kesehatan secara terpadu dalam bidang Pendidikan Kedokteran, pendidikan berkelanjutan, dan pendidikan kesehatan lainnya secara multiprofesi ${ }^{1}$. Wahana Pendidikan Kedokteran adalah fasilitas selain Rumah Sakit Pendidikan yang digunakan sebagai tempat penyelenggaraan Pendidikan Kedokteran ${ }^{1}$. Dalam menjalankan tugasnya selama masa pendidikan profesi, dokter muda diberi kesempatan terlibat dalam pelayanan kesehatan dengan bimbingan dan pengawasan dosen, yang berarti dokter muda memiliki kesempatan berinteraksi yang sama dengan tenaga medis yang lain ${ }^{1}$.

WHO menyatakan bahwa kekerasan terhadap tenaga medis, termasuk pada dokter muda, sangat rentan terjadi di seluruh dunia dengan angka kejadian sebesar $8 \%$ hingga $38 \%$, bergantung pada kondisi negara tersebut ${ }^{4}$. Kekerasan pada dokter muda tercatat mencapai $36 \%$ di Turki, $38 \%$ di Amerika Serikat, 59\% di Iran, serta 63\% di Tiongkok setidaknya pernah sekali mengalami kekerasan di wahana pendidikan klinis selama masa pendidikan ${ }^{5-8}$. Sayangnya, karena keterbatasan aturan, kurangnya pemahaman akan prosedur pelaporan, serta normalisasi 
kejadian menyebabkan banyak kasus akhirnya tidak terlaporkan dan tidak terselesaikan ${ }^{9-11}$.

Pada akhirnya, terlepas dari risiko profesi, insiden kekerasan seperti ini tentu memberi dampak pada para korban dan penyintasnya, meliputi post-traumatic stress disorder, kecemasan, ketakutan, depresi, serta menurunnya kualitas dalam pelayanan pasien ${ }^{12}$. Jika tidak segera ditangani, kasus seperti ini juga akan mengarah pada ketidakpuasan akan pekerjaan hingga penurunan kualitas hidup ${ }^{13}$.

Mayoritas kasus kekerasan pada dokter muda terjadi karena kurangnya kemampuan berkomunikasi dengan pasien dan kurangnya rasa percaya dalam hubungan dokter dengan pasien $^{14}$. Hal tersebut merupakan salah variabel-variabel yang bisa dicegah dengan penerapan kode etik yang baik. Etika profesi dokter diatur dalam Kode Etik Kedokteran Indonesia, terdiri dari prinsip umum aturan profesi serta norma fungsional guna menjaga hubungan kepercayaan dokter dengan pasien. Kode etik kedokteran juga diciptakan dengan maksud untuk lebih nyata menjamin dan mewujudkan kesungguhan dan keluhuran ilmu kedokteran ${ }^{15}$.

Berdasarkan buku panduan kepaniteraan klinik yang dikeluarkan beberapa Fakultas Kedokteran di Indonesia, dalam melaksanakan pendidikannya, dokter muda diharapkan untuk turut serta mempelajari, berusaha menghayati, serta mulai mengamalkan Kode Etik Kedokteran Indonesia dalam setiap kegiatan yang berhubungan dengan upaya pemeliharaan kesehatan masyarakat ${ }^{16,17}$. Pemahaman terhadap kode etik berdampak baik pada perilaku yang mampu mencegah terjadinya konflik $^{18}$.

Penelitian ini bertujuan untuk mengetahui adanya hubungan pengetahuan Kode Etik Kedokteran Indonesia dengan kejadian kekerasan di wahana pendidikan klinis.

\section{METODE}

Penelitian ini merupakan penelitian observasional analitik dengan pendekatan cross sectional dan dilaksanakan di RSUD dr. Moewardi Kota Surakarta pada bulan JanuariFebruari 2020 dengan subjek penelitian adalah dokter muda.

Metode pengambilan sampel yang digunakan adalah purposive sampling, dengan kriteria setiap dokter muda di RSUD dr. Moewardi yang telah menjalani pendidikan profesi dokter selama lebih dari sama dengan 6 bulan. Besar sampel menggunakan rule of thumb sejumlah minimal 30 orang.

Instrumen penelitian menggunakan kuisioner yang dibagi menjadi empat bagian. Bagian paling awal merupakan lembar informed consent. Bagian selanjutnya merupakan biodata subjek penelitian. Bagian ketiga merupakan lembar uji pengetahuan tentang Kode Etik Kedokteran Indonesia yang memuat 50 pertanyaan berdasarkan pasal kewajiban umum dan kewajiban terhadap pasien. Pada bagian ini terdapat dua pilihan jawaban (benar dan salah) jika jawaban responden benar, akan bernilai 1 dan jika salah diberi nilai 0 . Bagian terakhir merupakan lembar angket (kuisioner) tentang kejadian kekerasan di wahana pendidikan klinis yang diukur dalam enam kategori, yakni kekerasan fisik, kekerasan verbal, pelecehan seksual, pelecehan atas dasar SARA, perundungan, dan pengancaman. Pilihan jawaban terdiri dari jumlah frekuensi kejadian kekerasan yang diterima dalam 6 bulan terakhir. Pemberian skor dilakukan dengan memberi nilai 1 jika menjawab tidak pernah, 2 jika menjawab sangat jarang (1-2 kali), 3 jika menjawab jarang (3-5 kali), 4 jika menjawab sering (5-10 kali), dan 5 jika menjawab sangat sering ( $>10$ kali).

Data selanjutnya dianalisis dengan uji prasyarat berupa uji normalitas, uji validitas, uji reabilitas, dan uji linearitas. Bila data terdistribusi normal dan linier, maka 
selanjutnya data akan dianalisis dengan uji korelasi Pearson dan uji regresi linier sederhana

\section{HASIL}

Didapatkan 54 responden yang memenuhi kriteria inklusi yang terdiri dari dokter muda stase ilmu kedokteran forensik dan medikolegal, kulit, THT, mata, dan ilmu kesehatan jiwa. Dari 50 pertanyaan yang diuji, terdapat 31 pertanyaan yang dinyatakan valid secara statistika $(p>0,195)$ dan kuisioner penelitian juga dinyatakan reliabel $(p>0,6)$.

\section{Data Demografi Responden}

Tabel 1 menunjukan data demografi pasien yang menjadi sampel penelitian yang terdiri dari usia, jenis kelamin, lama menjalani pendidikan profesi, dan asal suku.

Tabel 1. Data Demografi Responden

\begin{tabular}{|c|c|c|}
\hline $\begin{array}{c}\text { Data } \\
\text { Demografi } \\
\text { Responden }\end{array}$ & Jumlah & Persentase \\
\hline Usia (tahun) & & \\
20-24 & 47 & $87 \%$ \\
25-29 & 7 & $13 \%$ \\
\hline Jenis Kelamin & & \\
Perempuan & 41 & $75,9 \%$ \\
Laki-Laki & 13 & $24,1 \%$ \\
\hline Lama & & \\
Menjalani & & \\
Pendidikan & & \\
Profesi & & \\
(Bulan) & & \\
6-10 & 16 & $29,6 \%$ \\
11-15 & 19 & $35,2 \%$ \\
16-20 & 14 & $25,9 \%$ \\
>20 & 5 & $9,3 \%$ \\
\hline Asal Suku & & \\
Jawa & 40 & $74,1 \%$ \\
Batak & 4 & $7,5 \%$ \\
Melayu & 3 & $5.6 \%$ \\
Dayak & 2 & $3,8 \%$ \\
Banjar & 1 & $1,8 \%$ \\
Sunda & 1 & $1,8 \%$ \\
Tionghoa & 1 & $1,8 \%$ \\
Papua & 1 & $1,8 \%$ \\
Campuran & 1 & $1,8 \%$ \\
\hline
\end{tabular}

\section{Data Pengetahuan Kode Etik Kedokteran Indonesia}

Berdasarkan tabel 2, terlihat persebaran data berdasarkan nilai variabel pengetahuan Kode Etik Kedokteran Indonesia. Data menunjukkan bahwa mayoritas responden (22.2\%) mendapat skor 26. Skor tertinggi berada pada nilai 31 , dan terendah pada nilai 12, masing-masing berjumlah 1 responden.

Tabel 2. Distribusi Data berdasarkan Nilai Variabel Pengetahuan Kode Etik Kedokteran Indonesia

\begin{tabular}{ccc}
\hline Nilai & Jumlah & Persentase \\
\hline 12 & 1 & $1.8 \%$ \\
13 & 1 & $1.8 \%$ \\
19 & 2 & $3.7 \%$ \\
20 & 1 & $1.8 \%$ \\
22 & 2 & $3.7 \%$ \\
23 & 7 & $13 \%$ \\
24 & 6 & $11.2 \%$ \\
25 & 6 & $11.2 \%$ \\
26 & 12 & $22.2 \%$ \\
27 & 9 & $16.7 \%$ \\
28 & 4 & $7.4 \%$ \\
29 & 2 & $3.7 \%$ \\
31 & 1 & $1.8 \%$ \\
\hline
\end{tabular}

\section{Data Kekerasan di Wahana Pendidikan Klinis}

Berdasarkan tabel 3, terdapat 35 responden $(64.8 \%)$ yang pernah mengalami kekerasan di wahana pendidikan klinis setidaknya sekali dalam kurun waktu 6 bulan terakhir serta 19 responden $(35.25 \%)$ tidak pernah mengalami kekerasan di wahana pendidikan klinis. Jenis kekerasan yang paling sering dijumpai berupa kekerasan verbal, yakni sebanyak $88 \%$ dari seluruh kejadian kekerasan di wahana pendidikan klinis. Pelaku kekerasan di wahana pendidikan klinis yang paling sering dilaporkan adalah keluarga pasien $(57.1 \%)$, disusul dengan pengunjung umum $(45.7 \%)$, dan pasien $(25.7 \%)$. 
Tabel 3. Gambaran Kekerasan di Wahana Pendidikan Klinis

\begin{tabular}{lcc}
\hline \multicolumn{1}{c}{ Variabel } & Jumlah & Persentase \\
\hline Kejadian & & \\
Pernah & 35 & $64.8 \%$ \\
Tidak Pernah & 19 & $35.2 \%$ \\
Jenis Kekerasan & & \\
Kekerasan Fisik & 9 & $25.7 \%$ \\
Kekerasan Verbal & 31 & $88.6 \%$ \\
Pelecehan Seksual & 12 & $34.3 \%$ \\
Perundungan & 16 & $48.6 \%$ \\
Pelecehan SARA & 14 & $40.0 \%$ \\
Pengancaman & 10 & $28.6 \%$ \\
Pelaku Kekerasan & & \\
Pasien & 9 & $25.7 \%$ \\
Keluarga Pasien & 16 & $57.1 \%$ \\
Pengunjung Umum & 20 & $45.7 \%$ \\
\hline
\end{tabular}

Keterangan: dalam memilih jawaban untuk jenis kekerasan dan pelaku kekerasan, subjek penelitian dapat memilih lebih dari satu jawaban.

Berdasarkan tabel 4, terlihat persebaran data berdasarkan nilai variabel kejadian kekerasan di wahana pendidikan klinis. Data menunjukkan bahwa mayoritas responden $(35,2 \%)$ memiliki skor 6 , yang juga merupakan skor terendah. Skor tertinggi berada pada nilai 21 yang dimiliki oleh seorang responden

Tabel 4. Distribusi Data berdasarkan Nilai Kejadian Kekerasan di Wahana Pendidikan Klinis

\begin{tabular}{ccc}
\hline Nilai & Jumlah & Persentase \\
\hline 6 & 19 & $35.2 \%$ \\
7 & 8 & $14.8 \%$ \\
8 & 3 & $5.6 \%$ \\
9 & 7 & $13.0 \%$ \\
10 & 5 & $9.3 \%$ \\
11 & 3 & $5.6 \%$ \\
12 & 4 & $7.4 \%$ \\
14 & 2 & $3.7 \%$ \\
15 & 1 & $1.8 \%$ \\
17 & 1 & $1.8 \%$ \\
21 & 1 & $1.8 \%$ \\
\hline
\end{tabular}

\section{Analisis Hasil Data Penelitian}

Hasil uji normalitas pada penelitian ini memiliki nilai signifikansi (p) sebesar 0.200 ( $p>0.005)$. Sementara pada uji linieritas, $p$ bernilai 0.253 ( $p>0.05)$, sehingga data penulis dapat dianalisis menggunakan uji korelasi Pearson dan uji regresi linier sederhana.

Tabel 5. Hasil Pengolahan Data

\begin{tabular}{clc}
\hline & & $\begin{array}{c}\text { Kekerasan } \\
\text { di wahana } \\
\text { pendidikan klinis }\end{array}$ \\
\hline Pengetahuan & $\mathrm{r}$ & -0.313 \\
KODEKI & $\mathrm{p}$ & 0.021 \\
& $\mathrm{r}^{2}$ & 0.098 \\
& Persamaan & $16,696-0,364 \mathrm{x}$ \\
& regresi & \\
\hline
\end{tabular}

Berdasarkan tabel 5, didapatkan koefisien korelasi (r) sebesar -0.313 $(0.2<\mathrm{r}<0,399)$ dan nilai signifikansi (p) sebesar $0.021 \quad(\mathrm{p}<0.05)$ dari 54 responden. Interpretasi data hasil penelitian ini adalah terdapat korelasi yang signifikan secara statistik antara variabel pengetahuan Kode Etik Kedokteran Indonesia dengan variabel kekerasan di wahana pendidikan klinis. Kekuatan korelasi lemah dan arah korelasi negatif sehingga semakin tinggi nilai variabel pengetahuan Kode Etik Kedokteran Indonesia maka semakin rendah kejadian kekerasan di wahana pendidikan klinis yang dialami dokter muda.

Pada analisis hasil uji regresi linier sederhana, didapatkan nilai koefisien determinasi $\left(r^{2}\right)$ sebesar 0.098. Hal ini memiliki makna bahwa variabel pengetahuan Kode Etik Kedokteran Indonesia memiliki pengaruh sebesar $9.8 \%$ terhadap terjadinya kekerasan di wahana pendidikan klinis. Sementara interpretasi persamaan regresinya adalah konstanta sebesar 16.696 menyatakan bahwa jika tidak ada nilai pengetahuan Kode Etik Kedokteran Indonesia maka nilai kekerasan di wahana pendidikan klinis akan 
menunjukkan angka 16.696. Kefisien regresi $\mathrm{x}$ sebesar -0.364 menyatakan bahwa setiap penambahan 1 nilai pengetahuan Kode Etik Kedokteran Indonesia, maka akan mengurangi nilai kekerasan di wahana pendidikan klinis sebanyak 0.364 .

\section{PEMBAHASAN}

Data nilai pengetahuan Kode Etik Kedokteran Indonesia pada tabel 2 menujukkan tingkat pengetahuan yang beragam. Hal ini dapat dilihat melalui data demografi responden pada tabel 1 yang menunjukkan perbedaan latar belakang suku, usia, lama menjalani pendidikan profesi, dan jenis kelamin. Selain itu, pengetahuan juga didukungoleh budaya yang mendukung pembelajaran ${ }^{16}$. Jawaban responden yang cenderung bervariasi menunjukkan adanya pertimbangan pengetahuan maupun pengalaman selama pendidikan yang telah diperoleh.

Data peneliti yang dianalasis menggunakan uji korelasi Pearson menunjukkan nilai probabilitas (p) dengan derajat kemaknaan penelitian <0,05. Pada nilai koefisien korelasi (r) didapatkan nilai 0.313 atau berada $-1<\mathrm{r}<1$ yang dimaksudkan bahwa $\mathrm{H}_{0}$ ditolak dan $\mathrm{H}_{1}$ diterima sehingga dapat dinyatakan terdapat hubungan negatif lemah pengetahuan kode etik kedokteran dengan kejadian kekerasan di wahana pendidikan klinis pada dokter muda.

Berdasarkan beberapa studi, terdapat kaitan antara pemahaman kode etik dengan manajemen konflik. Pemahaman kode etik berdampak baik pada perilaku yang mampu mencegah terjadinya konflik $^{18}$. Mahasiswa kedokteran yang memahami kode etik dan regulasi profesi juga akan menunjukkan respek yang lebih tinggi terhadap etik profesi, profesionalisme, hukum, dan praktik kedokteran $^{20}$.

Walaupun pengetahuan merupakan salah satu faktor yang berkontribusi terhadap terbentuknya sikap seseorang, namun tidak dipungkiri faktor lain seperti bakat, minat, pengalaman, perasaan maupun kondisi lingkungan juga mengambil peranan ${ }^{21}$. Hal ini membuat jawaban kuisioner pengetahuan Kode Etik Kedokteran Indonesia yang berisi tentang kewajiban umum dan kewajiban terhadap pasien memiliki variasi jawaban sejalan dengan beragamnya latar belakang responden. Variasi pengetahuan akan mebimbulkan variasi pada sikap yang ditunjukkan, sebagai hasilnya akan timbul variasi respon yang diterima.

Namun, pada pengolahan data dengan regresi, didapatkan nilai koefisien determinasi $\left(\mathrm{r}^{2}\right)$ memiliki nilai 0.098. Angka ini menunjukkan bahwa pengetahuan Kode Etik Kedokteran Indonesia hanya berkontribusi sebesar $9.8 \%$ terhadap terjadinya kekerasan di wahana pendidikan klinis sementaa $90.2 \%$ sisanya berasal dari faktor yang lainnya. Nilai ini secara teori dapat diterima karena faktor penyebab terjadinya kekerasan tidak dapat dijelaskan hanya dengan satu variabel. Nilai ini secara teori dapat diterima karena faktor penyebab terjadinya kekerasan tidak dapat dijelaskan hanya dengan satu variabel. Kekerasan merupakan hasil dari hubungan kompleks antara faktor individu, komunitas, budaya, serta lingkungan ${ }^{22}$.

Beberapa penelitian menunjukkan bahwa penyebab kekerasan di tempat kerja merupakan kejadian yang multifaktorial. Penelitian yang dilakukan The Joint Commission dengan subjek penelitian tenaga kesehatan menunjukkan bahwa kekerasan di tempat kerja tidak hanya berasal dari faktor individu tenaga medis itu sendiri namun juga menyoriti beban kerja yang menumpuk sehingga pelayanan tidak prima ${ }^{23}$. Berdasarkan studi kasus kekerasan di tempat kerja yang dikeluarkan oleh WHO, ILO, PCN, dan PSI dengan subjek tenaga kesehatan di Thailand, faktor yang berkontribusi terhadap terjadinya kekerasan bisa dilihat dari tiga sektor, yakni faktor individu (pelaku dan 
korban), faktor pekerjaan, serta faktor lingkungan fisik ${ }^{24}$. Faktor individu korban meliputi, jenis kelamin, usia, status pernikahan, asal suku, dan kondisi psikososial $^{24}$. Faktor pekerjaan meliputi, pengalaman bekerja, shift saat bekerja, lokasi kerja, jenis tempat kerja, jenis layanan kesehatan yang disediakan, serta bagian tempat bekerja ${ }^{24}$. Faktor individu dari pelaku meliputi faktor psikososial $^{24}$. Faktor lingkungan fisik meliputi rancang bangun yang buruk, misalnya jalan penghubung antar ruangan yang gelap, sepi, dan tanpa pengawasan ${ }^{24}$. Penelitian ini juga menyoroti faktor internal pusat layanan kesehatan seperti kebijakan kerja, pengelolaan sumber daya manusia, ataupun stresor internal (seperti senioritas, beban pekerjaan, permasalahan antar pegawai, serta isu kesejahteraan pegawai) ${ }^{24}$.

Faktor-faktor individu lainnya seperti kepribadian yang lemah serta performa pekerjaan yang kurang baik. Kurangnya kemampuan dalam berhubungan interpersonal dengan pasien, seperti kemampuan berkomunikasi dan penyelesaian konflik, termasuk minimnya porsi pelatihan kemampuan interpersonal dalam kurikulum pendidikan kedokteran, dituding menjadi salah satu penyebab terjadinya kekerasan di tempat kerja ${ }^{25-27}$. Sementara penelitian lain menyoroti bahwa waktu tunggu yang lama, ketidakpuasan terhadap perawatan, keterlambatan tindakan medis, stres psikologi, kurangnya pengamanan, pengawasan, dan tindak lanjut dari manajemen rumah sakit, ataupun pengaruh alkohol dan/atau obatobatan mampu menyebabkan terjadinya peningkatan risiko kekerasan di tempat $\operatorname{kerja}^{27,28}$.

Meskipun kejadian kekerasan di wahana pendidikan klinis tidak hanya bergantung pada pengetahuan etik masingmasing individu, kode etik merupakan pedoman berperilaku yang seharusnya bisa digunakan untuk meminimalisir terjadinya kekerasan. Peran etika profesi dalam hal ini adalah untuk mengimbangi sisi negatif sebuah profesi dengan kepercayaan masyarakat akan suatu profesi serta menjamin bahwa kepentingannya keduanya tidak terganggu ${ }^{29}$. Pengetahuan yang memadai mengenai kode etik menimbulkan sikap yang sesuai dengan ketentuan yang harusnya dilakukan. Namun, pencegahan terjadinya kekerasan harus secara jelas dan lengkap menganalisis faktor personal (baik korban maupun pelaku), institusional (lingkungan dan struktur tempat kerja), serta lingkungan masyarakat dan daerah $^{30}$.

Penelitian ini menguatkan anggapan bahwa faktor internal memiliki kontribusi terhadap terjadinya kekerasan, yakni ketika semakin tinggi pengetahuan tentang kode etik kedokteran, maka semakin rendah kejadian kekerasan yang diterima. Hasil penelitian ini dapat dijadikan salah satu bahan pertimbangan dalam perumusan peraturan guna mencegah terjadinya kekerasan di wahana pendidikan klinis.

Keterbatasan yang didapatkan dalam penelitian ini antara lain: 1) pengendalian subjek penelitian seperti faktor-faktor perancu yang mempengaruhi hasil penelitian, seperti beban kerja yang tinggi, bekerja di unit perawatan kritis; 2) penulis melakukan pengambilan sampel menggunakan kuesioner yang memiliki beberapa kelemahan seperti kesalahan interpretasi oleh responden, angket terlihat membosankan dan penulis tidak dapat mengobservasi langsung responden dalam menjawab; 3) subjek penelitian yang penulis gunakan cenderung homogen yaitu dokter muda di rumah sakit yang sama (RSUD dr. Moewardi) sehingga pengambilan subjek penelitian belum dapat digeneralisasikan secara umum karena dokter muda di setiap rumah sakit mempunyai perbedaan; 4) Penulis hanya melakukan pengukuran langsung terhadap pengetahuan, bukan sikap.

Saran yang penulis ajukan antara lain:

1) Perlunya peningkatkan pembelajaran 
mengenai kode etik kedokteran pada mahasiswa, khususnya untuk mengurangi risiko terjadinya kekerasan di wahana pendidikan klinis, contohnya dengan lebih memaksimalkan kurikulum skillslab dengan topik komunikasi efektif, negosiasi, ataupun manajemen konflik; 2) Peningkatkan

pelayanan pengaduan kekerasan di wahana pendidikan klinis, termasuk sosialisasi, tata cara pelaporan, sekaligus memberikan pelatihan rutin pada dokter muda untuk meningkatkan pemahaman dalam mengurangi risiko terjadinya kekerasan di wahana pendidikan klinis; 3) Perlu dilakukan penelitian secara berkala guna mengevaluasi kejadian kekerasan di wahana pendidikan klinis serta dampaknya pada dokter muda guna mengambil langkah strategis untuk menanggulanginya; 4) Perlu dilakukan penelitian lebih lanjut dengan ukuran sampel lebih besar dan lebih beragam dengan melibatkan dokter muda dari wahana pendidikan klinis lain untuk memperkecil peluang kesalahan generalisasi; 5) Perlu dilakukan penelitian lebih lanjut untuk menelusuri faktor-faktor lain yang mempengaruhi terjadinya kekerasan di wahana pendidikan klinis.

\section{KESIMPULAN}

Terdapat hubungan dan pengaruh yang bermakna secara statistik antara pengetahuan kode etik kedokteran dengan kejadian kekerasan di wahana pendidikan klinis dengan dengan kekuatan lemah dan arah korelasi negatif.

\section{UCAPAN TERIMA KASIH}

Penulis mengucapkan terima kasih kepada Dr. Hari Wujoso, dr, Sp.F.,M.M yang telah memberikan bimbingan, saran, dan kritik yang membangun selama penelitian hingga penulisan naskah publikasi ini. Apresiasi juga penuulis haturkan untuk seluruh rekan dokter muda yang sudah berkenan membantu menyebar dan mengisi kuisioner penelitian ini.

\section{DAFTAR PUSTAKA}

1. Pemerintah Indonesia. Undang-Undang Nomor 20 Tahun 2013 tentang Pendidikan Kedokteran. 2013.

2. Yenealem DG, Woldegebriel MK, Olana AT, Mekonnen TH. Violence at work: Determinants \& prevalence among health care workers, northwest Ethiopia: An institutional based cross sectional study. Ann Occup Environ Med. 2019;31(1):1-7.

3. ILO, ICN, WHO, PSI. Framework guidelines addressing workplace violence in the health sector. International Labour Office (ILO), International Council of Nurses (ICN), World Health Organization (WHO), Public Services International (PSI). 2002. $35 \mathrm{p}$.

4. World Health Organization. Violence Against Health Workers [Internet]. 2018. Available from:

https://www.who.int/violence_injury_preventio n/violence/workplace/en/

5. Ince $\mathrm{A}$, Torun $\mathrm{P}$, Ahmed $\mathrm{S}$, Jadoo $\mathrm{A}$. Workplace violence against medical studentsA Turkish perspective. 2019;2(1):70-4.

6. Association of American Medical Colleges. Medical School Graduation Questionnaire: 2016 All Schools Summary Report. 2016.

7. Afkhamzadeh A, Mohamadi Bolbanabad A, Moloudi B, Safari H, Piroozi B. Workplace violence against physicians and medical students in west part of Iran. Int J Hum Rights Healthc. 2019;12(2):116-23.

8. Chung MP, Thang CK, Vermillion M, Fried JM, Uijtdehaage S. Exploring medical students' barriers to reporting mistreatment during clerkships: a qualitative study. Med Educ Online. 2018;23(1).

9. ALBashtawy M, Aljezawi M. Emergency nurses' perspective of workplace violence in Jordanian hospitals: A national survey. Int Emerg Nurs. 2016;24:61-5.

10. Phillips JP. Workplace violence against health care workers in the United States. N Engl J Med. 2016;374(17):1661-9.

11. Rawung S, Panelewen J, Sentinuwo SR. Faktor - Faktor yang Berhubungan dengan Kekerasan pada Perawat Instalasi Gawat Darurat Rumah Sakit di Kota Manado. [Tesis] Manado: Universitas Sam Ratulangi; 2017

12. Embree JL, White AH. Concept Analysis: Nurse-to-Nurse Lateral Violence. Nurs Forum. 2010;45(3):166-73. 
13. Zeng JY, An FR, Xiang YT, Qi YK, Ungvari GS, Newhouse R, et al. Frequency and risk factors of workplace violence on psychiatric nurses and its impact on their quality of life in China. Psychiatry Res. 2013;210(2):510-4.

14. Xie Z, Li J, Chen Y, Cui K. The effects of patients initiated aggression on Chinese medical students' career planning. BMC Health Serv Res. 2017;17(1):1-8.

15. Pengurus Besar Ikatan Dokter Indonesia. Kode Etik Kedokteran Indonesia. 2012.

16. Fakultas Kedokteran Universitas Indonesia. Buku Pedoman Praktik Klinik Mahasiswa FK UI. Jakarta: FK UI; 2009.

17. Badan Koordinasi Pendidikan Fakultas Kedokteran Universitas Sebelas Maret - RSUD Dr. Moewardi. Buku Pedoman Program Studi Profesi Dokter. Surakarta: FK UNS; 2016.

18. Brown D. The impact of codes of ethics on behaviour A rapid evidence assessment. J Coll Polic. 2014;

19. Lunden A, Teräs M, Kvist T, Häggman-Laitila A. A systematic review of factors influencing knowledge management and the nurse leaders' role. J Nurs Manag. 2017;25(6):407-20.

20. Chin JJL, Voo TC, Abdul Karim S, Chan YH, Campbell A V. Evaluating the effects of an integrated medical ethics curriculum on firstyear students. Ann Acad Med Singapore. 2011;40(1):4-18.

21. Suharyat Y. Hubungan antara Sikap, Minat, dan Perilaku Manusia. 2009.

22. World Health Organization. Violence - A Global Public Health Problem. In: World Report on Violence And Health. 2002.

23. The Joint Commission. Physical and verbal violence against health care workers. Sentin Event Alert. 2018;(59).

24. Sripichyakan K, Pathraporn T, Supavititpatana B. Workplace Violence In The Health Sector: A Case Study in Thailand. Chiangmai; 2003.

25. Sharma S, Singh G, Gautam PL, Sharma S, Kaur A, Bhatia N, et al. Questionnaire-based Evaluation of Factors Leading to Patientphysician Distrust and Violence against Healthcare Workers. Indian J Crit Care Med. 2019;23(7):302-9.

26. Steinman S. Workplace Violence In The Health Sector: A Case Study in South Africa. Geneva; 2003.

27. Yousefi P, Salehi B, Sanginan T. The types and contributing factors of aggression toward physicians and students of medicine in hospitals of Arak in 2009. Arak Med Univ J. 2010;13(2):155-64.

28. Abdellah RF, Salama KM. Prevalence and risk factors of workplace violence against health care workers in emergency department in Ismailia, Egypt. Pan Afr Med J. 2017;26:1-8.

29. Bertens K. Etika (Edisi Revisi). Jakarta: Kanisius; 2015.

30. Ogenler O, Yapici G. Patient-physician relationship in medical ethics education in the context of violence against healthcare workers : A short review. Int J Orig Res. 2016;2(8):296300 . 